\title{
Hydrotherapy and crenotherapy in the treatment of pain: integrative review
}

\author{
Hidroterapia e crenoterapia no tratamento da dor: revisão integrativa
}

Juliane de Macedo Antunes ${ }^{1}$, Donizete Vago Daher ${ }^{1}$, Vania Maria de Araújo Giaretta ${ }^{2}$, Maria Fernanda Muniz Ferrari ${ }^{1}$, Maria Belén Salazar Posso ${ }^{2}$

DOI 10.5935/2595-0118.20190033

\section{ABSTRACT}

BACKGROUND AND OBJECTIVES: The Integrative and Complementary Practices were implemented in the Unified Health System as adjunctive modalities in the treatment of pain. This article focuses on crenotherapy and hydrotherapy, whose agents are the natural mineral waters and common for the rehabilitation of functional alterations. The scarcity of these practices for the treatment of pain in the literature justifies this review. This study aimed to check the scientific productions about the efficacy of balneology/balneotherapy/crenotherapy and hydrotherapy in the treatment of pain.

CONTENTS: It is an integrative review, carried out in May 2018, searching in the electronically available scientific articles, in full, in the LILACS, Pubmed, BVS and CINAHL database in periodicals published in the last 10 years focusing on crenotherapy and hydrotherapy for pain relief, in the Portuguese, English and Spanish language. The descriptors used were: "Pain", "Balneology", "Crenotherapy", "Hydrotherapy" "Efficacy"; "Effectiveness" in the three languages, combined with the Boolean expressions AND/Y/E and OR/O/U/OU, finding 2306 articles, of which 111 were identified, and only 27 met the inclusion criteria, analyzed and incorporated the evidence that emerged in pain relief.

CONCLUSION: This study showed that most of the evidence emerged from the studies analyzed regarding the efficacy of hydrotherapy and balneology in pain pictures focused on levels 1 to 3 . Of the 27 studies, 18 showed the efficacy of hydrotherapy and eight of balneology in the pain symptomatology and one in relation to the lack of knowledge of the use of these complementary therapies in pain relief.

Keywords: Balneology, Balneotherapy, Crenotherapy, Efficacy, Hydrotherapy, Pain.

Juliane de Macedo Antunes - Dhttps://orcid.org/0000-0002-9763-8291;

Donizete Vago Daher - (Dhttps://orcid.org/0000-0001-6249-0808;

Vania Maria de Araújo Giaretta - (Dhttps://orcid.org/0000-0003-4231-5054;

Maria Fernanda Muniz Ferrari - Dhttps://orcid.org/0000-0001-6606-8938;

Maria Belén Salazar Posso - (Dhttps://orcid.org/0000-0003-3221-6124.

1. Universidade Federal Fluminense, Niterói, RJ, Brasil.

2. Universidade de Taubaté, Sáo Paulo, SP, Brasil.

Submitted on July 04, 2018.

Accepted for publication on May 02, 2019.

Conflict of interests: none - Sponsoring sources: none.

Correspondence to:

Rua Iperoig, 749-111 - Perdizes

05016-000 São Paulo, SP, Brasil.

E-mail: mbelen@terra.com.br

(c) Sociedade Brasileira para o Estudo da Dor

\section{RESUMO}

JUSTIFICATIVA E OBJETIVOS: As Práticas Integrativas e Complementares foram institucionalizadas no Sistema Único de Saúde como modalidades coadjuvantes no tratamento da dor. Este artigo focalizou a utilizaçáo de crenoterapia e hidroterapia, cujos agentes são as águas minerais naturais, comum para a reabilitação de alteraçôes funcionais. A escassez da literatura dessas práticas no tratamento da dor, justifica esta revisão. O objetivo deste estudo foi verificar a produçấo cientifica sobre a eficácia da balneologia/balneoterapia/crenoterapia e da hidroterapia no tratamento da dor.

CONTEÚDO: Revisão integrativa, realizada em maio de 2018, cuja busca de artigos científicos disponíveis eletronicamente e na íntegra, na base de dados, LILACS, Pubmed, BVS e CINAHL em periódicos publicados nos últimos 10 anos enfocaram a crenoterapia e hidroterapia para o alívio da dor nos idiomas Português, Inglês e Espanhol. Os descritores utilizados foram: Dor, Balneologia, Crenoterapia, Hidroterapia, Eficácia; nos três idiomas, combinados com as expressóes booleanas $A N D / Y / \mathrm{E} \mathrm{e}$ $O R / \mathrm{O} / \mathrm{U} / \mathrm{OU}$ encontrando 2306 artigos, identificados 111 e destes, apenas 27 atenderam aos critérios de inclusão, analisados e incorporadas as evidências emergidas no alívio da dor.

CONCLUSÂO: Este estudo mostrou que a maioria das evidências emergidas dos trabalhos analisados quanto à eficácia da hidroterapia e crenoterapia em processos álgicos concentraram-se nos níveis 1 a 3. Dos 27 estudos, 18 mostraram a eficácia da hidroterapia e oito da balneoterapia e crenoterapia nos sintomas dolorosos, e um em relação ao desconhecimento do uso dessas práticas integrativas no alívio da dor.

Descritores: Balneologia, Balneoterapia. Crenoterapia, Dor, Eficácia, Hidroterapia.

\section{INTRODUCTION}

In 2002, the World Health Organization (WHO) ${ }^{1}$ established the Pain Management Protocol for the relief of pain and in the document "WHO Traditional Medicine Strategy 2002-2005" recognizing the importance, efficacy, and quality of Complementary Medicine, encouraging the integration of their knowledge to those of the Western Medicine in health systems. The text of this Strategy continues with the encouragement of the use of Integrative and Complementary Practices (PICS) for the development of access policies, for rational, responsible, safe practice and at the same time, recommending the development of studies that validate them ${ }^{1}$. 
The PICS were institutionalized in the Unified Health System (SUS) by the National Policy on Integrative and Complementary Practices (PNPIC), approved by Ordinance GM/MS No. 971/5/3/20062. The purpose of the Ministry of Health (MS) ${ }^{2}$ is to offer the Brazilian population access to PICS by standardizing them to meet the demands of the public health network, being transversal in its actions in the Unified Health System (SUS), and present at all levels of health care, making available to the population modalities to follow: aromatherapy, art therapy, ayurveda, biodance, bioenergetics, family constellation, chromotherapy, circular dance, geotherapy, hypnotherapy, homeopathy, imposition of hands, anthroposophic medicine/anthroposophy, applied to health, Traditional Chinese Medicine - acupuncture, auriculotherapy, meditation, music therapy, naturopathy, osteopathy, ozone therapy, phytotherapy, chiropractic, reflexotherapy, reiki, shantala, integrative community therapy, floral therapy, social thermalism/cryotherapy and yoga ${ }^{2}$. Except for acupuncture, that is minimally invasive; the others are characterized by non-invasive interventions and an important rebalancing of the physical, mental, and emotional energies.

These PICS help the pharmacological treatment and alleviate the suffering caused by pain, considered one of the great public health problems, improving the quality of life $(\mathrm{QoL})^{3,4}$. Pain is a symptom frequently present in the patient and requires physical, psychosocial, and psychoemotional evaluation determining the agent of his/her suffering by the multiprofessional team ${ }^{3-5}$.

This article will specifically focus on the use of hydrotherapy (HT) (common water) and crenotherapy (CT) (thermal water) for pain relief, which have water as an essential element. The different modes of therapeutical application of water receive the names of social thermalism, balneotherapy (BT), thalassotherapy, CT, and $\mathrm{HT}^{2}$.

The BT/CT designation refers to the therapeutic use of natural mineral waters whose chemical composition can be classified as sulphurated, radioactive, bicarbonate, ferruginous, among others, for the prevention, treatment, and rehabilitation of various diseases. It is a millenary practice introduced in Brazil by the Portuguese empire for the treatment of several organic signs and symptoms of patients, as a complementary therapy to other treatments ${ }^{2,5}$.

HT consists of the external and therapeutic use of common water with different application and temperature forms. It is an important resource for the rehabilitation of functional alterations, having as a principle the physical, chemical, physiological, and kinesiological effects obtained by immersion of the body in swimming pool ${ }^{6,7}$, usually heated. Exercises in the heated water improve joint movement, relaxation, reduction of muscle tension, muscular spasms, an increase of muscle strength and endurance $^{6}$, besides benefiting the venous return, improving peripheral circulation and favoring the decrease of pain ${ }^{6,7}$.

HT and CT do not present associated risks, being a convenient method, but they must be used with discretion, responsibility, and performed by trained professionals $s^{2,6,7}$. HT and CT, although they are millenarian therapeutic methods, like PICS used for the treatment of pain, seem to have been little contemplated in scientific studies in the national and international literature. This study aimed to evaluate the efficacy of CT and HT in the treatment of pain through an integrative review of the literature.

\section{CONTENTS}

It is an integrative review that allows the search, the critical evaluation, the synthesis, analysis, and incorporation of the evidence of the national and international scientific productions emerged from the subject investigated ${ }^{8,9}$, with a retrospective temporal cut, respecting the copyright of the literature used, according to Law No. 9610/1998 of the Ministry of Education and Culture (MEC) ${ }^{10}$.

After, the following steps were followed: 1. establishment of the guiding question; 2. objective; 3 . criteria for inclusion and exclusion of articles; 4 . information extracted from selected articles; 5 . analysis and presentation of the studies ${ }^{8,9}$. The guiding question was: "How does national and international scientific production evaluate the efficacy of HT and BT/CT in pain therapy"?

The databases used were: Latin American and Caribbean Health Sciences Literature (LILACS), Virtual Health Library (VHL); Cumulative Index to Nursing and Allied Health Literature (CINAHL) and National Library of Medicine (Pubmed) using controlled descriptors from the Health Sciences Descriptors (DeCS) and the Medical Subject Headings (MeSH), "dor (pain,) (dolor); eficácia (efficacy/effectiveness), (eficácia); BT/CT (balneology) (crenotherapy) and (hydrotherapy) (HT). Also used an uncontrolled descriptor: hidrotherapy (crenotherapy) two or more $\mathrm{DeCS} / \mathrm{MeSH}$ among those mentioned were combined and the Boolean expressions E/AND/Y/ and OU/OR/O/U (Table 1)

Table 1. Combination of descriptors with Boolean expressions used in the search strategy (EB)

\begin{tabular}{|c|c|}
\hline EB & $\begin{array}{l}\text { Combination of the descriptors with the Boolean expres- } \\
\text { sions } E / A N D / Y / \text { and } O U / O R / O / U\end{array}$ \\
\hline $1 \mathrm{a}$ & $\begin{array}{l}\text { Balneoterapia e dor (balneology, balneologia and/y pain/ } \\
\text { dolor) }\end{array}$ \\
\hline $2 a$ & Crenoterapia e dor (crenotherapy/and/y pain/dolor) \\
\hline 3a & Hidroterapia e dor (hydrotherapy/and/y pain/dolor) \\
\hline $4 a$ & $\begin{array}{l}\text { Balneoterapia e dor ou crenoterapia e dor; (balneology bal- } \\
\text { neologia and/y pain or crenotherapy and/y pain, dolor) }\end{array}$ \\
\hline $5 a$ & $\begin{array}{l}\text { Balneoterapia e dor e eficácia ou crenoterapia e dor e efi- } \\
\text { cácia (balneology and pain, dolor and efficacy or effecti- } \\
\text { veness or crenotherapy and/y efficacy or effectiveness, or } \\
\text { eficácia, efetividade and/y pain, dolor. }\end{array}$ \\
\hline $6 a$ & Hidroterapia e dor (hydrotherapy, and pain, hidroterapia dolor) \\
\hline $7 a$ & $\begin{array}{l}\text { Hidroterapia e dor e eficácia ou terapia aquática, dor e } \\
\text { eficácia ou (hydrotherapy and pain, dolor and efficacy or } \\
\text { effectiveness, eficácia, efetividade). }\end{array}$ \\
\hline
\end{tabular}

The review period was from May 2008 to May 2018, seeking to cover more recent studies of CT and HT and its efficacy in pain relief. The inclusion criteria were: scientific papers in English, Spanish and Portuguese available electronically and excluded editorials, letters, theses, dissertations, monographs, manuals, abstracts of congresses; articles duplicated in more than one database, counting only one; or that did not address the research question, the objective and descriptors.

After the critical and careful reading of the abstracts and, a posteriori, of the complete articles, the information was organized and recorded in a specially structured form, composed to identify title, author, year of publication, objectives, methods and 
results of articles analyzed, including or excluding them for the analysis, presentation of the main results and classification of the emerging evidence.

The precepts of the PRISMA checklist, $2009^{11}$ were considered to analyze meta-analyzes and systematic reviews that guide the eligibility, inclusion of articles, and the level of scientific evidence (LE), favoring the preparation of figure 1 .

The search was carried out independently by 2 reviewers who after the refinement of the searches, classified the quality, scientific validity, and reliability of the articles by the Level of Evidence (LE) ${ }^{12,13}$, that is, level 1: the evidence from systematic review or meta-analysis of relevant randomized controlled trials or from clinical guidelines based on systematic reviews of randomized controlled trials; level 2, evidence derived from at least one well-delineated randomized controlled trial; level 3, evidence obtained from well-delineated non-randomized controlled trials; level 4, evidence from well-delineated cohort and case-control studies; level 5, evidence originating from a systematic review of descriptive and qualitative studies; level 6, evidence derived from a single descriptive or qualitative study; level 7, evidence from the opinion of authorities and/or report of expert committees"12,13.

The analysis of table 2 shows that of the 1,160 articles screened in the databases, 1,049 were excluded because they did not meet the inclusion criteria, with 111 articles remaining eligible. After the evaluation of the full text, 84 were excluded, of which only 27 were included. One article (3.7\%) was found in VHL (IBEC), and five articles (18.5\%) were found in LILACS, none in CINAHL database and $21(77.8 \%)$ in Pubmed from a total of 27 analyzed.

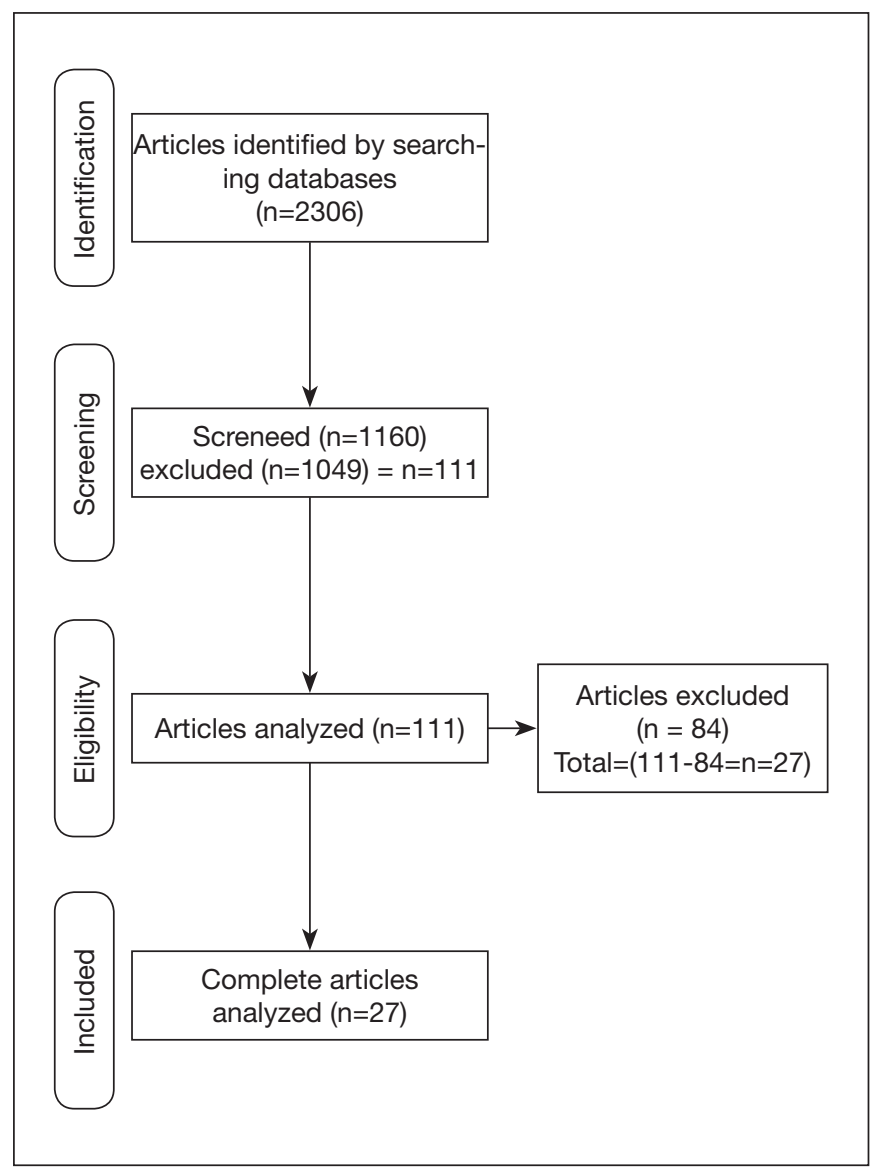

Figure 1. Flowchart with eligibility representation and inclusion of articles

Table 2. Summarized registry of titles, author, periodical, year, database, objectives, method, and results

\begin{tabular}{|c|c|c|c|c|c|}
\hline Articles & $\begin{array}{l}\text { Authors and } \\
\text { database }\end{array}$ & $\begin{array}{l}\text { Type of studies } \\
\text { and } n\end{array}$ & Synthesis & Conclusion & $\begin{array}{l}\text { Level of } \\
\text { evidence }\end{array}$ \\
\hline A1 & $\begin{array}{l}\text { Ceylan e } \\
\text { Bollşlk }{ }^{14} \\
\text { Pubmed }\end{array}$ & $\begin{array}{l}\text { Crossover de- } \\
\text { sign, experimen- } \\
\text { tal, randomized } \\
\text { controlled trial. } \\
n=35\end{array}$ & $\begin{array}{l}35 \text { socio-demographically homogeneous } \\
\text { premature infants with } 33-37 \text { weeks' } \\
\text { gestation with a birth weight }<1,500 \mathrm{~g} \\
\text { in the NICU were selected from a pub- } \\
\text { lic hospital in Denizli, Turkey. Two bath } \\
\text { methods: } 20 \text { babies of the Experimental } \\
\text { Group wrapped with tissue (EG) and } 15 \\
\text { wrapped with a sponge of the Control } \\
\text { Group (CG) were applied at intervals of } \\
3 \text { days. Vital signs and oxygen saturation } \\
\text { levels were measured before and at min- } \\
\text { utes } 1,5,15,30 \text { after bathing. The mean } \\
\text { water temperature was } 37.76 \pm 0.16^{\circ} \mathrm{C} \text { for } \\
\text { CG and } 37.58 \pm 0.8^{\circ} \mathrm{C} \text { for EG. Video-re- } \\
\text { corded baths evaluated pain and stress } \\
\text { behaviors by independent observers. } \\
\text { p<0.05 was used for all statistical analy- } \\
\text { sis; excluded babies with signs of infec- } \\
\text { tion, neurological problems, skin integri- } \\
\text { ty, congenital defects, deterioration, use } \\
\text { of analgesic drugs, sedatives or muscle } \\
\text { relaxants. The bath application sequence } \\
\text { was computer-randomized (Predictive } \\
\text { Analytics Software, SPSS Inc., Chicago, } \\
\text { IL, USA). }\end{array}$ & $\begin{array}{l}\text { The baby's bath wrapped with } \\
\text { fabric has a positive effect on the } \\
\text { baby's vital signs, oxygen satura- } \\
\text { tion levels, cry time, and level of } \\
\text { stress and pain compared to the } \\
\text { condition of the common bath. } \\
\text { The pain scores of the babies } \\
\text { during and after the tissue baths } \\
\text { were smaller ( } p=0.001 \text { ) than } \\
\text { the standard baths. Baby bath } \\
\text { wrapped in fabric is a harmless } \\
\text { and safe nursing practice }\end{array}$ & 2 \\
\hline
\end{tabular}


Table 2. Summarized registry of titles, author, periodical, year, database, objectives, method, and results - continuation

\begin{tabular}{|c|c|c|c|}
\hline Articles & $\begin{array}{l}\text { Authors and } \\
\text { database }\end{array}$ & $\begin{array}{l}\text { Type of studies } \\
\text { and } n\end{array}$ & Synthesis \\
\hline A2 & $\begin{array}{l}\text { Avila et al. }{ }^{15} \\
\text { Pubmed }\end{array}$ & $\begin{array}{l}\text { Experimental } \\
\text { before and af- } \\
\text { ter, non-ran- } \\
\text { domized. } \\
n=20\end{array}$ & $\begin{array}{l}20 \text { women with fibromyalgia syndrome } \\
\text { with pain and restriction of three-dimen- } \\
\text { sional scapular movement underwent } 3 \\
\text { evaluation sessions, one before, one after } \\
8 \text { weeks and at the end of } 16 \text { weeks of } \\
\text { a hydrotherapy treatment program with } 2 \\
\text { sessions of } 45 \text { min/weekly/ } 16 \text { weeks. Data } \\
\text { were analyzed by ANOVA for pain and } \\
\text { quality of life variables. The effect on the } \\
\text { scapular movement evaluated by Cohen's } \\
\text { coefficient d. The pain intensity by VAS }=8 \\
\text { at the time before compared with evalua- } \\
\text { tions } 2 \text { and } 3 \text { at the time after, evolved to } \\
\text { zero intensity. }\end{array}$ \\
\hline A3 & $\begin{array}{l}\text { Batten et al. }{ }^{16} \\
\text { Pubmed }\end{array}$ & $\begin{array}{l}\text { Experimental, } \\
\text { non-random- } \\
\text { ized, before and } \\
\text { after. } \\
n=43\end{array}$ & $\begin{array}{l}\text { The normal postpartum HT protocol without } \\
\text { drug use was aimed at relieving the pain of } \\
45 \text { women who were immersed in hot water } \\
\text { for } 30 \text { minutes and } 1 \text { hour postpartum. The } \\
\text { pain scores were evaluated before the bath, } \\
15 \text { and } 30 \text { minutes later. There was a signifi- } \\
\text { cant reduction in scores. }\end{array}$ \\
\hline
\end{tabular}

A4 Cipriano and Oliveira $^{17}$ LILACS

Matsumoto et Meta-analysis al. ${ }^{18} \quad \mathrm{n}=102$

A5 Pubmed

A6

Vanderlaan $^{19}$ Pubmed

Experimental, The authors verified the influence of elasprospective, tic bandaging in the treatment of posterior non-random- pelvic pain and functionality in the activities ized controlled of the daily life of pregnant women. It is a

Pubmed
trial. $\mathrm{n}=20$ controlled and prospective clinical trial with 20 pregnant women, 10 in each group, aged between 18 and 39 years old: experimental group (EG) (elastic bandage and $\mathrm{HT}$ ) and control group (CG) (HT). The pain was evaluated by the numerical visual scale (NVS) and the functionality through the Rolland-Morris disability questionnaire.

Meta-analysis performed in the databases: Medline, Embase, Cochrane Library and in the database of the Japan Medical Abstracts Society using two approaches, MeSH terms (Medical Subject Headings) and free words published from 2004 to $12 / 31 / 2016$ in the English or Japanese languages of randomized controlled trials of 102 publications involving 734 patients(359 EG and $375 \mathrm{CG}$ ), analyzing the effect of balneotherapy/crenotherapy (BT/CT) for the treatment of pain, stiffness and improvement of physical function compared to patients with osteoarthritis of the knee lasting $\geq 2$ weeks. The Osteoarthritis Index (WOMAC) and VAS for pain were used. They analyzed the improvement in the WOMAC score in the final follow-up ranging from 2 to 12 months postintervention.

Retrospective The use of HT for pain management in lacohort study, $\mathrm{n}=164$ bor in 268 participants. Of these, 80 were excluded by medical decision, and 24 evolved to pharmacological treatment. The mean duration of immersion use was 156.3min \pm 122.7 at $\mathrm{T} \pm 37^{\circ} \mathrm{C}$.

Conclusion
The proposed HT program was
effective in improving quality of
life, pain intensity ( $\mathrm{p}<0.05)$, re-
flecting the improvement of the
scapular movement from -1.93 to
1.61 and the impact of fibromy-
algia in women with this disease.

This treatment significantly reduced VAS pain $=8$ between the onset of the bath and $2(p$ $<0.001$ ) at 15 and 30 minutes and $(p=0.97)$ between the two times. It offered a non-pharmacological alternative, in which there are traditionally limited options.

They concluded that there was no statistical difference between the two groups $(p<0.05)$ with these two evaluation instruments for the treatment of posterior pelvic pain and the improvement of functionality in daily activities in pregnant women. An elastic bandage can be used to treat low back pain during pregnancy safely.

This meta-analysis indicated that BT/CT was clinically effective in relieving pain, stiffness, and improvement of function, as evaluated by the WOMAC score, compared to controls with high heterogeneity (88 to $93 \%$ ).

The induction of labor was associated with a decline in the supply of HT during labor provided comfort, besides being a non-pharmacological strategy, low cost, safe and effective, promotes normal delivery.
Level of evidence 
Table 2. Summarized registry of titles, author, periodical, year, database, objectives, method, and results - continuation

\begin{tabular}{|c|c|c|c|}
\hline Articles & $\begin{array}{l}\text { Authors and } \\
\text { database }\end{array}$ & $\begin{array}{l}\text { Type of studies } \\
\text { and } n\end{array}$ & Synthesis \\
\hline A7 & $\begin{array}{l}\text { Koyuncu et } \\
\text { al. }{ }^{20} \\
\text { Pubmed }\end{array}$ & $\begin{array}{l}\text { Experimental } \\
\text { rand o m ized } \\
\text { controlled trial. } \\
n=60\end{array}$ & $\begin{array}{l}\text { The authors investigated the efficacy } \\
\text { of BTCT in relieving chronic neck pain } \\
\text { of } 60 \text { patients, randomized into two } \\
\text { groups: experimental (EG) ( } n=30 \text { ) and } \\
\text { control (CG) ( } n=30 \text { ). All patients in both } \\
\text { groups were treated with a physiothera- } \\
\text { py program (FT) of } 15 \text { standard sessions } \\
\text { consisting of hot pack, ultrasound and } \\
\text { TENS. The EG patients were also treat- } \\
\text { ed by the BT/CT program of } 15 \text { sessions } \\
\text { lasting } 20 \text { minutes/day. VAS, modified } \\
\text { neck disability index (mNDI) and Not- } \\
\text { tingham health profile score (NHT) were } \\
\text { used for all patients, being evaluated at } \\
\text { three different times as pretreatment, } \\
\text { posttreatment and the third week after } \\
\text { treatment. The } 2 \text { groups were homoge- } \\
\text { neous both socioeconomically and clin- } \\
\text { ically. Intergroup analysis revealed the } \\
\text { superiority of EG in all parameter. }\end{array}$ \\
\hline
\end{tabular}

Branco et al. ${ }^{21}$ PubMed LILACS non-randomized controlled trial. $n=26$

Fonseca et al. ${ }^{23}$ Before and afPubmed

Conclusion
The authors conclude that com-
bined therapy of BT/CT and FT
provided clear clinical improve-
ment and remains long-term. All
EG parameters were superior to
FT alone in reducing pain and
improving the quality of life of pa-
tients with chronic neck pain.

Level of evidence
Pain intensity decreased significantly during movement, at rest and at night, as well as analgesic use, with even better WOMAC, LAFI and HAQ scores from baseline to T2 and T3 $(p<0.001)$. Both AS and TM methods were effective in the treatment of OAK. AS baths produced a good impact of clinical rehabilitation in reducing pain and improving physical function in OAK patients.
There was an improvement in the ability to perform ADL and physical capacity, as well as a decrease in pain with a mean pre-treatment of $8.9 \pm 1.2$ and $5.1 \pm 1.7(p<0.0001)$ and significant improvement in capacity to increase range of movement.

HT decreased muscle pain (3.1 \pm 1.0 versus $1.5 \pm 1.1(p=0.004)$ and improved post-workout recovery, increased muscle strength compared to passive recovery $(p=0.0058)$, LDH levels were lower than those in the control group $(p=0.03)$. Higher perceived muscle power in HT than in control for both upper limbs $p=0.001$, HT has been widely applied as a recovery method; however, there are few publications demonstrating the evidence of its efficacy. 
Table 2. Summarized registry of titles, author, periodical, year, database, objectives, method, and results - continuation

\begin{tabular}{|c|c|c|c|c|c|}
\hline Articles & $\begin{array}{l}\text { Authors and } \\
\text { database }\end{array}$ & $\begin{array}{l}\text { Type of studies } \\
\text { and } n\end{array}$ & Synthesis & Conclusion & $\begin{array}{l}\text { Level of } \\
\text { evidence }\end{array}$ \\
\hline A11 & $\begin{array}{l}\text { Forestier, Erol } \\
\text { Forestier and } \\
\text { Francon }{ }^{24} \\
\text { Pubmed }\end{array}$ & $\begin{array}{l}\text { Syst e matic } \\
\text { review of ran- } \\
\text { domized exper- } \\
\text { imental studies } \\
\mathrm{n}=36\end{array}$ & $\begin{array}{l}\text { Systematic review of } 421 \text { randomized } \\
\text { controlled trials in the Medline databas- } \\
\text { es via Pubmed, PEDRO, and Cochrane } \\
\text { Central Register of controlled clinical } \\
\text { trials. Of these, only } 36 \text { were included } \\
\text { up to September } 2015 \text {. Inclusion: ar- } \\
\text { ticles from experimental randomized } \\
\text { controlled trials on knee osteoarthri- } \\
\text { tis (OAK) with separate data from hot } \\
\text { mineral water baths, mud therapy, hot } \\
\text { showers, and supervised massage and } \\
\text { water exercises (EG), compared with any } \\
\text { other intervention or no treatment (CG); } \\
\text { follow-up> } 3 \text { months, pain measurement } \\
\text { and/or function and/or overall evaluation } \\
\text { of the patient and quality of life at } 3,6 \\
\text { and } 9 \text { months. }\end{array}$ & $\begin{array}{l}\text { A review of } 36 \text { randomized } \\
\text { controlled trials covering } 2833 \\
\text { patients with high heterogeneity } \\
(88 \text { to } 93 \%) \text { showed that HT and } \\
\text { CT treatment performed in SPA } \\
\text { centers in Europe and the Mid- } \\
\text { dle East seem to improve pain } \\
\text { and the function of patients with } \\
\text { OAK. When CT is associated } \\
\text { with exercise program demon- } \\
\text { strates superiority to home ex- } \\
\text { ercise only for pain and function } \\
\text { at } 3,6 \text { and } 9 \text { months with no dif- } \\
\text { ference in the quality of life and } \\
\text { drug consumption. }\end{array}$ & 1 \\
\hline
\end{tabular}

$\begin{array}{lll}\text { A12 Chen et al. }{ }^{25} & \text { Meta-analysis } \\ \text { Pubmed } & \mathrm{n}=15\end{array}$

Seven databases were searched: PubMed, the Cochrane Library, Springer; China National Knowledge Infrastructure, Chongqing VIP, Chinese Biomedical, and Wanfang by October 2014. Randomized controlled trials evaluating 2 weeks of Chinese Herbal Bath Therapy (CHBT) for OAK were selected. The effects of CHBT on clinical symptoms and pain level (VAS). The meta-analysis of 15 studies with 1618 individuals who met the eligibility criteria was performed. The bath prescription included, on average, 13 Chinese herbs with instructions for using steam and washing around the knee for 20 to 40 minutes, once or twice a day. The mean duration of treatment was 3 weeks.

A13 Ezheltha Suji Before and after To evaluate the efficacy of foot bath verand Sharmila experimental, sus exercises in reducing pain among paJansi Rani ${ }^{26}$ non-random- tients with OAK. Sixty patients with OAK Pubmed ized controlled trial. and ankle were selected by intentional sampling at Issac Bone \& Joint Specialty Hospital, Marthandam in Kanyakumari district. Demographic, clinical, and VAS variables of group I and group II were collected before and after the administration of the foot bath versus exercises on the first, third, and fifth days of treatment. The analysis was done using descriptive and inferential statistics.

A14 Ibarra Cornejo Systematic re- Systematic review of randomized conet al. ${ }^{27}$ view of experBVS (IBECS)

\section{imental, ran-} domized controlled trials $n=6$
Chinese herbal bath therapy may be effective in reducing OAK pain (mean difference -0.59 points, $p<0.00001)$, when compared to standard Western treatment. No serious adverse events have been reported.

There was a significant association between age, disease duration, family history of osteoarthritis, physical mobility, and any condition associated with osteoarthritis and the level of pre-test pain among patients. The results showed that foot bath (0.52) had a better effect on reducing joint pain in knees and ankles than in exercises $(1,20)(p<0.001)$. (1.20) $(p<0.001)$.

The authors inferred that the primary studies included showed strong evidence that $\mathrm{HT}$ was effective in reducing pain in all (mean $\mathrm{p}<0.003$ ) and improved quality of life and physical function in patients with osteoarthritis of the knee at 6 to 12 weeks of follow-up 
Table 2. Summarized registry of titles, author, periodical, year, database, objectives, method, and results - continuation

\begin{tabular}{|c|c|c|c|}
\hline Articles & $\begin{array}{l}\text { Authors and } \\
\text { database }\end{array}$ & $\begin{array}{l}\text { Type of studies } \\
\text { and } n\end{array}$ & Synthesis \\
\hline A15 & $\begin{array}{l}\text { Karagülle and } \\
\text { Karagülle }^{28} \\
\text { Pubmed }\end{array}$ & $\begin{array}{l}\text { Syste matic } \\
\text { review of ran- } \\
\text { domized con- } \\
\text { trolled trials } \\
n=8\end{array}$ & $\begin{array}{l}\text { The objective was to evaluate the recent } \\
\text { evidence on the efficacy of BT and SPA } \\
\text { therapy for patients with low back pain. The } \\
\text { databases for RCT published in Pubmed } \\
\text { and Cochrane Central Register between } \\
07 / 2005 \text { and } 12 / 2013 \text {. The Jadad scale was } \\
\text { used to classify the methodological quality } \\
\text { of eligibility, and of the total of } 114 \text {, left } 8 \text {, } \\
\text { being three with scores } 3 \text {, indicating good } \\
\text { quality. All trials tested the efficacy of BT/CT } \\
\text { versus common water in SPA for low back } \\
\text { pain. Of the } 8 \text { RCTs: } 2 \text { in BT and } 6 \text { in SPA } \\
\text { therapy. }\end{array}$ \\
\hline
\end{tabular}

A16 Liu et al. ${ }^{29}$

Pubmed

A17 Baena-Beato et al. ${ }^{30}$

Pubmed

A18 Baena-Beato et $\mathrm{al}^{31}$ Pubmed
Experimental, non-randomized controlled trial. $\mathrm{n}=108$

Experimental, randomized controlled trial $\mathrm{n}=49$

Before and after, experimental, non-randomized controlled trial $\mathrm{n}=60$
108 healthy primiparous women with single gestations in labor in China were studied. Of these, 80 progressed to normal delivery, 38 (EG) (mean of $28.66 \pm 3.08$ years old) were immersed in water maintained at $35-38^{\circ} \mathrm{C}$ and $70(\mathrm{CG})$ (mean of $27.89 \pm 2.99$ years old) underwent conventional labor. Pain scores were evaluated (VAS) when cervical dilatation was $3 \mathrm{~cm}$ before entering the bathtub, and 30 and 60 min after.

To understand the physical and psychological factors and reduction of disability after the aquatic/HT exercise of 49 patients of both genders sedentary with chronic low back pain. The patients were randomized: in EG-E1 ( $n=24$, two months, five times/week) CG $(n=25)$ according to the aquatic space program.

Sixty patients were included 30 of each gender; between 50 and 60 years old; body mass index, between 21 and 27 $\mathrm{kg} / \mathrm{m}^{2}$ with chronic low back pain. The 8-week aquatic/HT therapy program was conducted in a $25 \times 6 \mathrm{~m}$ indoor pool, $140 \mathrm{~cm}$ deep and $30 / 31^{\circ} \mathrm{C}$ of $\mathrm{T}$ of water, and patients exercised 2 to 5 days/week. Each session lasted from 55 to $60 \mathrm{~min}$ utes, (10 minutes of warm-up, 20 to 25 minutes of aerobic exercises, 15 to 20 minutes of resistance exercises, and 10 minutes of recharge).

Conclusion Level of

Evidence from all RCTs indicates that the efficacy of BT/CT in low back pain is encouraging and reflects the consistency of previous evidence. All reported that BT/CT was superior in long-term therapy with tap water in pain reliever. Although when SPA therapy is combined with CT, geotherapy and/or exercises, and/or education is effective in the treatment of low back pain, it is superior or equally effective to short- and long-term control treatments.

The authors concluded that immersion of water during labor reduces pain with lower scores than in the control group at 30 min and $60 \mathrm{~min}$ after cervical dilatation of $3 \mathrm{~cm}$ respectively in both, $p<0.001)$. The symptoms of stress urinary incontinence (SUI) at 42 days postpartum were also higher in the CG (25.5\% to $6.1 \%$ (EG) $p=0.035$ and the rate of cesarean section was lower $(p=0.026)$. There was no significant difference $(p>0.05)$ in the duration of labor and postpartum bleeding and Apgar Index.

The authors concluded that the two-month intensive program of high-frequency (five times/week) HT significantly decreased levels of chronic low back pain and increased the mobilization of sedentary people; there were no changes in the standardized mental component $(p<0.114)$; increased quality of life $(p<0.001)$ and improved body composition and physical fitness of $p<0.01$ of EG. The CG did not present a significant change in any parameter.

Significant correlations were found between change in disability and VAS (resting, flexion and extension), curl-up and ranged from -0.353 to 0.582 , all other parameters $p<0.01$. Significant predictors of change in disability after treatment were improvement of resting pain, flexion and extension and abdominal muscle resistance with HT.
3

2 
Table 2. Summarized registry of titles, author, periodical, year, database, objectives, method, and results - continuation

\begin{tabular}{|c|c|c|c|}
\hline Articles & $\begin{array}{l}\text { Authors and } \\
\text { database }\end{array}$ & $\begin{array}{l}\text { Type of studies } \\
\text { and } n\end{array}$ & Synthesis \\
\hline A19 & $\begin{array}{l}\text { Bender et al. }{ }^{32} \\
\text { Pubmed }\end{array}$ & $\begin{array}{l}\text { Meta-analysis } \\
n=18\end{array}$ & $\begin{array}{l}\text { Meta-analysis of randomized controlled } \\
\text { trials with Hungarian hot springs, pub- } \\
\text { lished between } 1989 \text { and } 2012 \text { in the } \\
\text { Pubmed, Web of Science, Scopus, PEDro } \\
\text { and Web of Knowledge databases. A total } \\
\text { of } 122 \text { studies were identified, and } 18 \text { clin- } \\
\text { ical trials were included. Of these, } 5 \text { eval- } \\
\text { uated the effect of HT and CT on chronic } \\
\text { low back pain, } 4 \text { on OAK and } 2 \text { on hand } \\
\text { osteoarthritis and } 1 \text { evaluated BT/CT on } \\
\text { chronic pelvic inflammatory diseases, the } \\
\text { others } 6 \text { ) verified its effect on several labo- } \\
\text { ratory parameters. }\end{array}$ \\
\hline
\end{tabular}

A20 Larmer et al. ${ }^{33}$ Pubmed

A21 Lee et al. ${ }^{34}$ Pubmed

A22

Cechetti, Fabro and Martini ${ }^{35}$ LILACS
Systematic review of randomized controlled trials. $n=24$

A systematic review was conducted at databases: EBSCO Health Databases (including Medline, CINAHL and SPORT Discus and Ovid), AMED Aliado and Complementary Medicine, Scopus, Cochrane Library and PEDro including only randomized controlled trials in English that investigated the effect of HT on adult pain in any form of arthritis who had not undergone joint replacement surgery and that all had at least one patient-reported outcome (PRO) or VAS, published up to $08 / 2012$ for a total of 375 intervention studies, systematic reviews and critical reviews.149 studies were excluded, 122 documents of these were identified, only 24 were included.

Experimental, In order to verify the efficacy of hot HT randomized in labor pain and delivery experiences controlled trial $\mathrm{n}=80$ during the first stage of labor, 80 women were randomized: 41 in the $C G$ and 39 in the EG in the teaching maternity hospital of Taipei City. The EG was showered at a controlled temperature of $37^{\circ} \mathrm{C}$ for 20 minutes. After a full 5-minute bath, in the sitting or standing position, the women spent 15 minutes directing the shower water to any region of the body they desired. The CG received standard care. The pain and the delivery experience were evaluated using the VAS and the Labour Agentry Scale (LAS), respectively.

Systematic re- They analyzed the efficacy of HT in paview of clinical tients with hip and knee osteoarthrosis trials $\mathrm{n}=8$

Conclusion

Level of
evidence

CT significantly reduces pain caused by different musculoskeletal diseases, regardless of the qualitative and quantitative composition of mineral water, evidencing the beneficial effect of CT in pain with weight support and at rest in patients with joint and degenerative spinal diseases, as well as, in chronic pelvic inflammatory disease and antioxidant states.

Exercise in water has been shown to be effective in reducing pain by improving the function and performance of $A D L$ in people with arthritis. Few studies have demonstrated that HT is superior to other forms of exercise. More research is needed to develop a valid and reliable and reproducible method. Inadequate outcome measures may have affected HT research, possibly explaining the lack of high-quality evidence for this intervention.

HT with hot water is economical, convenient, easy to implement, and the authors further stated that this PIC reduced pain $(p<0.001)$. This non-pharmacological intervention has helped women in labor to participate fully in this process, with the continued support of health professionals, to feel comforted and to have a more positive overall delivery experience.

The authors showed that the studies analyzed show that HT in osteoarthrosis is effective when used to alleviate discomfort and pain, reflecting on the improvement of the quality of life of patients with this disease. The lack of studies related to HT makes it difficult the approach of the professional. with data collection in the Scielo, Medline, LILACS and Pubmed systems, listing articles in full, from 2003 to 2011.8 articles were found, of these, 3 address $\mathrm{HT}$ in treatment for OAQJ, and 5 only for OAK. From the collected articles, the tests that served as parameters for analysis were the WOMAC, Lequesne Index, VAS-pain, physical function, and muscle strength. 
Table 2. Summarized registry of titles, author, periodical, year, database, objectives, method, and results - continuation

\begin{tabular}{llll}
\hline Articles & $\begin{array}{l}\text { Authors and } \\
\text { database }\end{array}$ & $\begin{array}{l}\text { Type of studies } \\
\text { and } \mathrm{n}\end{array}$ & Synthesis \\
\hline A23 & Marques et & $\begin{array}{l}\text { Descriptive } \\
\text { qualitative and }\end{array}$ & In order to investigate the knowledge and \\
& al. ${ }^{36}$ & acceptance of PICS by physicians and SUS \\
LILACS & $\begin{array}{l}\text { cross-sectional } \\
\text { study, }\end{array}$ & users. Three physicians and 35 SUS users \\
& & PICS in the Basic Health Units (BHU).
\end{tabular}

A24 Stark and

Miller ${ }^{37}$

Pubmed

A25 Ferreira et al. ${ }^{38}$ Pubmed

Silva et al..$^{39}$ Pubmed
Before and after, experimental, non-randomized controlled trial $\mathrm{n}=24$

(n)

Before and after, experimental, non-randomized controlled trial $\mathrm{n}=8$
They explored the effects of bathing during labor using a single post-test pre-test group design at a small community hospital in Michigan. 24 women were observed for pain and comfort level. They used vital signs, VAS for pain, and the Gagge thermal comfort scale. The contractions were palpated in the shower by the physician.

To evaluate the effect of HT on pain and quality of life of patients with rheumatoid arthritis (RA), nine patients were selected, aged 56.4 \pm 5.2 years old, but only 8 were included, excluding those that were contraindicated, after physical therapy evaluation, also performed before and after treatment, including the application of the Short-Form-36 Questionnaire (SF-36) and evaluation of morning stiffness, pain and sleep quality by VAS. The treatment consisted of $10 \mathrm{HT}$ sessions of $45 \mathrm{~min}$ each, 2 times/week. The data were treated statistically, with $\mathrm{p}<0.05$.

Experimental, They aimed to evaluate the efficacy of HT blinded, ran- in 64 individuals of both genders with OAK domized clinical compared to individuals with OAK in floor trial $\mathrm{n}=57$ exercises. Randomized homogeneously from the Rheumatology Outpatient Clinic of the Hospital São Paulo (UNIFESP/EPM), performing exercises for 18 weeks. Patients with clinical and radiographic diagnosis of OAK were included with the American College of Rheumatology criteria in Western Ontario and WOMAC with 3 subscales: pain, stiffness and physical function and pain ranging from 30 to $90 \mathrm{~mm}$ in VAS the previous week. They were evaluated during walking, by VAS at rest and immediately after a walking test (50FWT) 50 feet $(15.24 \mathrm{~m})$, walking time measured in quick and comfortable steps during and the Lequesne Index. Measurements recorded by a blinded investigator at the beginning and at the 9 and 18 weeks after the intervention commenced. 57 patients concluded the study.

\begin{abstract}
Conclusion

tom

This study demonstrated that.

$100 \%$ did not know the PICS in general, and after a clear explanation of the researcher, $31.42 \%$ knew and would accept the use of phytotherapy, $51.42 \%$ acupuncture, $37.1 \%$ homeopathy, and none knew and would use CT. The 3 BHU physicians showed indifference, not acceptance, and acceptance, respectively. the implementation of outreach programs for patients and especially for physicians prescribing PICS.
\end{abstract}

There were significant differences in cervical dilatation $(p=0.001)$, tension and pain $(p=0.003)$ and fetal heart rate $(p=0.001)$ after $H T$, although effective in relieving pain, reducing anxiety, inducing relaxation, HT is rarely used during labor.

They concluded that HT is a very used resource in the rehabilitation of these patients with RA due to the physical properties and physiological effects of water and the proposal made possible an improvement in health-related quality of life $(p<0.05)$, reduction of pain symptoms $(p=0.004)$, morning stiffness $(p=0.003)$, and improvement in sleep quality $(p=0.006)$. After the treatment, it was possible to verify the reduction of morning stiffness and pain besides the improvement in sleep quality.

HT was superior to ground exercise in pain relief $(p<0.001)$ before and after walking during the last follow-up. The authors concluded that both types of exercises (HT and terrestrial) reduced knee pain and increased their function in participants with OAK. Water-based exercises are a suitable and effective alternative for pain reduction and improvements in WOMAC and Lequesne scores. Pain before and after 50FWT decreased significantly in both groups, but there was no significant difference in pain in the previous week between groups.
Level of evidence 
Table 2. Summarized registry of titles, author, periodical, year, database, objectives, method, and results - continuation

\begin{tabular}{|c|c|c|c|c|c|}
\hline Articles & $\begin{array}{l}\text { Authors and } \\
\text { database }\end{array}$ & $\begin{array}{l}\text { Type of studies } \\
\text { and } n\end{array}$ & Synthesis & Conclusion & $\begin{array}{l}\text { Level of } \\
\text { evidence }\end{array}$ \\
\hline A 27 & $\begin{array}{l}\text { Silva et al. }{ }^{40} \\
\text { BVS (LILACS) }\end{array}$ & $\begin{array}{l}\text { Experimental, } \\
\text { non-random- } \\
\text { ized controlled } \\
\text { trial. } \\
n=10\end{array}$ & $\begin{array}{l}\text { The authors compared the efficacy of HT } \\
\text { and TENS in improving the symptoms of } 10 \\
\text { patients with fibromyalgia ( } 48.8 \pm 9.8 \text { years } \\
\text { old) divided into } 2 \text { groups: one treated with } \\
\text { HT (EG) and one with TENS (CG). All sub- } \\
\text { jects were evaluated before and after treat- } \\
\text { ment for flexibility (by third finger-soil index), } \\
\text { pain (by VAS) health-related quality of life } \\
\text { (using the SF- } 36 \text { and Nottingham Health } \\
\text { Profile (NHP) questionnaires and depression } \\
\text { (by the Beck's inventory). The data were } \\
\text { treated statistically, with a significance level } \\
\text { set at } p<0.05 \text {. }\end{array}$ & $\begin{array}{l}\text { Both treatments were effec- } \\
\text { tive in improving physical } \\
\text { fitness, but TENS }(p \leq 0.007) \\
\text { provided better pain scores } \\
\text { and in a greater number of } \\
\text { analyzed variables than HT } \\
\text { ( } \mathrm{p} \leq 0.076) \text {, suggesting to be } \\
\text { more effective in the treat- } \\
\text { ment of fibromyalgia. How- } \\
\text { ever, patients treated with HT } \\
\text { could present better results if } \\
\text { the treatment time was longer, } \\
\text { since the therapeutic pool } \\
\text { may have greater effect on } \\
\text { conditioning and long-term } \\
\text { functional capacity. }\end{array}$ & 3 \\
\hline
\end{tabular}

$\overline{\mathrm{VAS}}=$ visual analog scale; $\mathrm{NICU}=$ neonatal intensive care unit; $\mathrm{ADL}=$ activities of daily living; $\mathrm{TENS}=$ transcutaneous electrical nerve stimulation; $\mathrm{HT}=$ hydrotherapy; $\mathrm{HB}=\mathrm{BT} / \mathrm{CT}=$ balneotherapy/cryotherapy; WOMAC = Western Ontario and McMaster Universities Osteoarthritis.

The critical analysis of the results (Table 2) showed that LEs ranged from 1 to 5, with $8(29.6 \%)$ three meta-analyzes ${ }^{18,25,32}$, five systematic reviews of RCTs (SRRCT) $24,27,28,33,35$ and 6 $(22.2 \%)$ randomized clinical trials (RCT) $)^{14,20,21,30,34,39}$ were found in LE 1 and 2 respectively; non-randomized controlled trials (NRCT) ${ }^{15-17,22,23,26,29,31,37-38,40} 11$ (40.7\%) (LE 3); a Cohort ${ }^{19}$ $(3,7 \%)$ in LE 4; in LE 5 only one (3.7\%) qualitative and quantitative descriptive study was identified ${ }^{36}$ and none in the LE 6 and 7. Therefore, the studies focused on the hierarchical levels of evidence 1 to $3^{12,13}$ considered high and moderate and when related to the quality of strong and sufficient evidence levels ${ }^{13}$, respectively, demonstrating that the PICS studied appear to be effective in pain control. However, they should be further explored and studied scientifically to validate them academically. Regarding the type of study, adding the meta-analysis ${ }^{18,25,32}$ (11.1\%) and SRRCT ${ }^{24,27,28,33,35}(18.5 \%)$ and RCT ${ }^{14,20,21,30,34,39}$ $(22.2 \%)$ had a total of $(51.8 \%)$ higher than the number of non-randomized clinical trials (NRCT) ${ }^{15-17,22-23,26,29,31,37-38,40}$ (40.7\%), ratifying the quality of evidence raised regarding the efficacy of BT/CT and HT in relieving pain of various symptoms. This study showed that the focus of $18(66.66 \%)$ articles focused on the efficacy of HT in the pain of several etiologies and eight $(29.6 \%)$ in CT in pain. Among these 18 articles, 11 (61.1\%) are NRCT ${ }^{15-17,22-23,26,29,31,37-38,40}$; six (33.3\%) of RCT ${ }^{14,20,21,30,34,39}$ and one of SRRCT $24,27,28,33,35$ (5.6\%) predominating those of osteoarticular origin, being (62.5\%) of LE 1 and three (37.5\%) of LE 2 of musculoskeletal origin, confirming the scientific rigor of the studies and the PICS are recommended for the treatment of these types of pain problem. An SRRCT ${ }^{28}$ has shown that evidence from RCTs on the efficacy of BT/CT in chronic low back pain is encouraging and reflects the consistency of previous evidence. Moreover, the authors ${ }^{28}$ suggest that well-designed, conducted and reported RCTs are needed to test short- and long-term effects to control pain and to demonstrate broader beneficial effects.
The PICS in question were included in PNPIC ${ }^{1}$ in 2006 in Brazil, whose scientific studies in the country are still incipient. However, "therapies are present in 9,350 establishments in 3,173 municipalities, of which $88 \%$ are offered in basic care. In 2017 , 1.4 million individual visits were recorded in PIC. In addition to the collective activities, the estimate is that about 5 million people per year participate in these practices in the SUS. Scientific evidence has shown the benefits of integrated treatment between conventional medicine and PICS"13.

The three meta-analyzes ${ }^{18,25,32}$ analyzed (LE1) evidenced the efficacy and beneficial results of CT(2) and HT(1) for pain control in knee osteoarthritis (OAK) and hand $(\mathrm{OAH})$, chronic low back pain, chronic pelvic pain, degenerative joint and spinal diseases, antioxidant occurrences, metabolic and inflammatory parameters, increasing blood flow and muscle relaxation. Also, HT with Chinese herbs ${ }^{25}$ may be effective in reducing OAK pain when compared to standard western treatment. Similarly, the five (27.7\%) SRRCT $24,27,28,33,35$ solidly demonstrated the efficacy of CT(2) and HT(5), when combined or even isolated, in labor pain, in the low back pain, arthritis and OAK, and in the hip and ankle.

Regarding the RCTs ${ }^{14,20,21,30,34,39}$ of LE2, the six (22.2\%) analyzed the efficacy of CT(2) and HT(4) concerning pain in labor, as in of the newborn (NB), musculoskeletal and osteoarticular. All showed a significantly better effect not only on the intensity of pain and stress but also on other parameters evaluated in comparison to the baseline condition of each one, demonstrating that these PICS are economical, harmless, effective and safe.

Analyzing the $11 \mathrm{NRCT}^{15-17,22,23,26,29,31,37,38,40}$ all investigated HT in several painful situations, as in pain in fibromyalgic women $^{15,40}$; in puerperae ${ }^{16}$; in the pelvic pain of pregnant women $^{17}$; in osteoarticular and musculoskeletal pain ${ }^{22,23,26,38,40}$, pain during labor ${ }^{29,37}$, all of which are effective in improving painful symptoms. 
This review also included a qualitative and quantitative cross-sectional study ${ }^{36}$ that investigated the knowledge and acceptance of PICs by SUS physicians and users to show the lack of knowledge of users and professionals, and also considering that such article could stimulate further research since $100 \%$ of the respondents ignored the existence of most PICS. This study finds resonance in another, eight years later, that verified the knowledge, and the use of PICS for pain control by the population of the larger cities of Vale do Paraíba Paulista ${ }^{41}$ with similar results, since of 100 respondents, only $17.5 \%$ knew and $82.5 \%$ did not know them. The population still does not know the PICs that the SUS offers, using in greater number the older therapy, acupuncture, which was already part of the SUS, which shows the importance of studying, explaining, disseminating and presenting the PICS and its advantages the community. Therefore, systematic, randomized and controlled studies are needed that result in high, strong and sufficient evidence ${ }^{13}$ of PICS in the treatment of pain, which render people partially or totally disabled, transiently or permanently, triggering stress, suffering, and loss of quality of life $(\mathrm{QoL})^{4}$,

The limiting factors for the actual realization of the use of PICS are the scarce scientific evidence of a strong and sufficient lev$\mathrm{el}^{13}$ and the lack of knowledge about their use by health professionals. However, even limited, it seems correct to say that this study showed the efficacy of CT and HT in the treatment of pain in organic changes such as the knee, hand and ankle osteoarthritis; the musculoskeletal; those of obstetric origin. It also warns of the need for further research on how PICS may contribute to pain relief and reiterates that it is now mandatory to measure, control and record it by EAS health professionals as the Fifth Vital Sign. Given the above, including PICs in the treatment of pain, is an important issue to ensure comprehensive health care.

\section{CONCLUSION}

Most of the evidence emerged from the studies analyzed focused on levels 1 to 3 regarding the effective use of PICS, CT, and HT. Of the 18 articles on the efficacy of HT, eight on CT in the pain charts of knee, hand and ankle and musculoskeletal osteoarthritis and one in obstetric pain.

In most studies, evidence for the efficacy of PICS, CT, and HT was focused on levels 1 to 3 . The efficacy of HT was demonstrated in 18 articles: five in labor pains, two in fibromyalgia, ten musculoskeletal and pain caused by osteoarthritis of the knee, hand, hip and ankle, and in an article concerning the pain of newborns. The efficacy of CT was evidenced in eight articles of musculoskeletal pain due to knee, hand, hip and ankle osteoarthritis; and a qualitative article that shows the lack of knowledge of users and professionals about the use of PICS in SUS. It also showed that there are few scientific subsidies to scientifically substantiate the use of HT and CT in the treatment of pain, needing to increase the knowledge of these PICs with actions of permanent education, and at the same time, stimulate the increase of the scientific production by the health professionals for the effective use of these PICS.

\section{REFERENCES}

1. World Health Organization. Traditional medicine strategy 2002-2005. Geneva: World Health Organization; 2002.

2. Brasil. Ministério da Saúde. Secretaria de Atenção à Saúde. Departamento de Atenção Básica. Política Nacional de Práticas Integrativas e Complementares no SUS - PNPIC SUS. Brasília: Ministério da Saúde; 2006.

3. Schveitzer MC, Esper MV, Silva MJ. Práticas Integrativas e Complementares na Atençáo Primária em Saúde: em busca da humanização do cuidado. O Mundo da Saúde, São Paulo. 2012;36(3):442-51.

4. Araujo LC, Romero B. Dor: avaliação do $5^{\circ}$ sinal vital. Uma reflexão teórica. Rev Dor. 2015;16(4):291-6.

5. Amaral HA, Cantista AP. Evidências Científicas da Medicina Termal - CT. Universidade de Porto. dissertaçấo de mestrado; 2010.

6. Candeloro JM, Caromano FA. Efeito de um programa de hidroterapia na flexibilidade e na força muscular de idosas. Rev Bras Fisioter. 2007;11(4):303-9.

7. Brasil. Ministério da Saúde. Secretaria de Atenção à Saúde. Departamento de Atenção Básica. Ministério da Saúde inclui 10 novas práticas integrativas no SUS. Disponível em: http://portalms.saude.gov.br/noticias/agencia-saude/42737-ministerio-da-saude-inclui-10-novas-praticas-integrativas-no-sus.Acesso 6/10/2018.

8. Mendes $\mathrm{KD}$, Silveira $\mathrm{RC}$, Galvão $\mathrm{CM}$. Revisão integrativa: método de pesquisa para a incorporaçăo de evidências na saúde e na enfermagem. Texto Contexto Enferm. 2008;17(4):758-64.

9. Galvăo CM, Sawada NO, Mendes IA. [In search of the best evidence]. Rev Esc Enferm USP. 2003;37(4):43-50. Portuguese.

10. Brasil. Ministério da Educaçấo e Cultura. Lei no 9.610, de 19 de fevereiro de 1998 Altera, atualiza e consolida a legislaçăo sobre direitos autorais e dá outras providências. MEC.19/02/1998.

11. Moher D, Liberati A, Tetzlaff J, Altman DG; PRISMA Group. Preferred reporting items for systematic reviews and meta-analyses: the PRISMA statement. Int J Surg. 2010;8(5):336-41

12. Galvão CM. Níveis de evidência. Editorial. Acta Paul Enferm. 2006;19(2):V.

13. Melnyk BM, Fineout-Overholt E. Making the case for evidence-based practice. In Melnyk BM, Fineout-Overholt E. Evidence based practice in nursing \& healthcare. A guide to best practice. Philadelphia: Lippincot Williams \& Wilkins; 2005. 3-24p.

14. Ceylan SS, Bollşlk B. Effects of swaddled and sponge bathing methods on signs of stress and pain in premature newborns: implications for evidence-based practice. Worldviews Evid Based Nurs. 2018;15(4):296-303.

15. Avila MA, Camargo PR, Ribeiro IL, Albuquerque-Sendín F, Zamunér AR, Salvini TF. Effects of a 16-week hydrotherapy program on three-dimensional scapular motion and pain of women with fibromyalgia: a single-arm study. Clin Biomech. 2017,49:145-54.

16. Batten M, Stevenson E, Zimmermann D, Isaacs C. Implementation of a hydrotherapy protocol to improve postpartum pain management. J Midwifery Womens Health. 2017;62(2):210-4

17. Cipriano P, Oliveira C. Influência da bandagem elástica kinesio tape e da hidroterapia na dor pélvica posterior e na funcionalidade nas atividades diárias de gestantes. Fisioter Bras. 2017;18(1):2-11.

18. Matsumoto H, Higino H, Hayashi K, Ideno Y, Wada T, Ogata T, et al. The effect of balneotherapy on the relief of pain, stiffness and physical function in patients with osteoarthritis of the knee: a meta-analysis. Clin Rheumatol. 2017;36(8):1839-47.

19. Vanderlaan J. Retrospective cohort study of hydrotherapy in labor. J Obstet Gyneco Neonatal Nurs. 2017;46(3):403-10.

20. Koyuncu E, Ökmen BM, Özkuk K, Taşoğlu Ö, Özgirgin N. The effectiveness of balneotherapy in chronic neck pain. Clin Rheumatol. 2016;35(10):2549-55.

21. Branco M, Rêgo NN, Silva PH, Archanjo IE, Ribeiro MC, Trevisani VF. Bath thermal waters in the treatment of knee osteoarthritis: a randomized controlled clinical trial. Eur J Phys Rehabil Med. 2016;52(4):422-30.

22. Kümpel C, Saadeddine I, Porto EF, Borba RG, Castro AA. Impacto de um programa estruturado de hidrocinesioterapia em pacientes com osteoartrite de joelho. Acta Fisiátr. 2016;23(2):51-6.

23. Fonseca LB, Brito CJ, Silva RJ, Silva-Grigoletto ME, da Silva WM Junior, Franchini E. Use of cold-water immersion to reduce muscle damage and delayed-onset muscle soreness and preserve muscle power in Jiu-Jitsu athletes. J Tthl Train. 2016;51(7):540-9.

24. Forestier R, Erol Forestier FB, Francon A. Spa therapy and knee osteoarthritis: a systematic review. Ann Phys Rehabil Med. 2016;59(3):216-26.

25. Chen B, Zhan H, Chung M, Lin X, Zhang M, Pang J, et al. Chinese herbal bath therapy for the treatment of knee osteoarthritis: meta-analysis of randomized controlled trials. Evid Based Complement Alternat Med. 2015;2015;949172.

26. Ezheltha Suji SD, Sharmila Jansi Rani SS. Effectiveness of hot foot bath versus exercises on reducing pain among patients with osteoarthritis. Int J Nurs Educ. 2015;7(3):70-5.

27. Cornejo JL, Reffers DG, Vergara DA, Maldonado EA, Munốz SR, Lara MJ. Effectiveness of hydrotherapy to reduce pain and improve quality of life and physical function in adults with knee osteoarthritis: a systematic review. Rev Soc Esp Dolor. 2015;22(4):168-74

28. Karagülle M, Karagülle MZ. Efficacy of balneotherapy and spa therapy for the treatment of chronic low back pain: a review of the most recent evidence. Clin Rheumatol. 2015:34(2):207-14. 
29. Liu Y, Liu Y, Huang X, Du C, Peng J, Huang P, et al. A comparison of maternal and neonatal outcomes between water immersion during labor and conventional labor and delivery. BMC Pregnancy Childbirth. 2014;14:160.

30. Baena-Beato PÁ, Artero EG, Arroyo-Morales M, Robles-Fuentes A, Gatto-Cardia MC, Delgado-Fernández M. Aquatic therapy improves pain, disability, quality of life, body composition and fitness in sedentary adults with chronic low back pain. A controlled clinical trial. Clin Rehabil. 2014;28(4):350-60.

31. Baena-Beato PÁ, Delgado-Fernández M, Artero EG, Robles-Fuentes A, Gatto-Cardia MC, Arroyo-Morales M. Disability predictors in chronic low back pain after aquatic exercise. Am J Phys Med Rehabil. 2014;93(7):615-23.

32. Bender T, Bálint G, Prohászka Z, Géher P, Tefner IK. Evidence-based hydro- and balneotherapy in Hungary--a systematic review and meta-analysis. Int J Biometeorol. 2014;58(3):311-23.

33. Larmer PJ, Bell J, O'Brien D, Dangen J, Kersten P. Hydrotherapy outcome measures for people with arthritis: a systematic review. N Zealand J Physiother. 2014;42(2):54-67.

34. Lee SL, Liu CY, Lu YY, Gau ML. Efficacy of warm showers on labor pain and birth experiences during the first labor stage. J Obstet Gynecol Neonatal Nurs.
2013;42(1):19-28.

35. Cechetti F, Fabro AQ, Martini DR. Reabilitaçâo aquática como recurso de tratamento da osteoartrose de quadril e joelho. Fisioter Bras. 2012;13(5):384-9.

36. Marques LA, Vale F, Vieira VR, Nogueira VA, Mialhe FL, Silva LC. Atençâo farmacêutica e práticas integrativas e complementares no SUS: conhecimento e aceitaçăo por parte da população. são joanense. Physis. 2011;21(2):663-74.

37. Stark MA, Miller MG. Barriers to the use of hydrotherapy in labor. J Obstet Gynecol Neonatal Nurs. 2009;38(6):667-75.

38. Ferreira LR, Pestana PR, Oliveira J, Ferrari RA. Efeitos da reabilitação aquática na sintomatologia e qualidade de vida de portadoras de artrite reumatóide. Fisioter Pesqui. 2008;15(2):136-41.

39. Silva LE, Valim V, Pessanha AP, Oliveira LM, Myamoto S, Jones A, et al. Hydrotherapy versus conventional land-based exercise for the management of patients with osteoarthritis of the knee: a randomized clinical trial. Phys Ther. 2008;88(1):12-21

40. Silva TF, Suda EY, Marçulo CA, Paes FH, Pinheiro GT. Comparaçấo dos efeitos da estimulaçấo elétrica nervosa transcutânea e da hidroterapia na dor, flexibilidade e qualidade de vida de pacientes com fibromialgia. Fisioter Pesqui. 2008;15(2):118-24. 